\section{Is sexual abuse a part of war? A 4-year retrospective study on cases of sexual abuse at the Kenyatta National Hospital, Kenya}

\author{
Mary W. Kuria, ${ }^{1}$ Lilian Omondi, ${ }^{2}$ \\ Yvonne Olando, ${ }^{3}$ Margaret Makenyengo, ${ }^{4}$ \\ David Bukusi ${ }^{5}$ \\ 1'Department of Psychiatry, University \\ of Nairobi; ${ }^{2}$ School of Nursing Sciences, \\ College of Health Science, University of \\ Nairobi; ${ }^{3}$ Psychologist, Private Practice; \\ ${ }^{4}$ Psychiatry Department, Kenyatta \\ National Hospital; ${ }^{5}$ Kenyatta National \\ Hospital Youth Centre, VCT and HIV \\ Prevention Unit, Kenya
}

\section{Abstract}

The harmful effects of sexual abuse are long lasting. Sexual abuse when associated with violence is likely to impact negatively on the life of the victim. Anecdotal reports indicate that there was an increase in the number of cases of sexual violence following the 2007 post election conflict and violence in Kenya. Although such increases in sexual abuse are common during war or conflict periods the above reports have not been confirmed through research evidence. The purpose of the current study is to establish the trend in numbers of reported cases of sexual abuse at Kenyatta National Hospital over a 4-year period (2006-2009). Data on sexually abused persons for the year 2006-2009 was retrieved from the hospitals record. A researcher designed questionnaire was used to collect relevant data from the completed Post Rape Care (PRC) form. The PRC-Ministry of Health no. 363 (MOH363) form is mandatorily completed by the physician attending the sexually abused patient. There was an increase in the number of cases of sexual abuse reported in 2007 election year in Kenya, with a statistically significant increase in the sexually abused male cases. Sexual crime is more prevalent when there is war or conflict.

\section{Introduction}

In Kenya's general elections of December 2007, there was a high political tension that culminated to post election violence, which extended to February 2008. Violence erupted in several parts of Kenya including the slums of Nairobi. Incidences of sexual abuse especially towards women, mainly gang rapes were reported to have increased. ${ }^{1}$ The violence ended after the signing of the peace accord between warring parties on 8th February, $2008 .^{2}$ An increase in the number of cases of sexually abused women and children was reported following the December 2007 election and the subsequent post election violence that extended into the first 2 months of year $2008 .{ }^{3}$ The number of sexually abused people attended at Kenyatta National Hospital (KNH) was reported to have gone up two months before the year 2007 December general elections and 2 months after. These attended cases were however said to be only 30 per cent of the actual figures with the majority going unreported. ${ }^{4}$ These reports have not been confirmed through research-based evidence.

History of sexual abuse is common and greatly increases the risk of developing psychiatric illness as well as the risk of attempted suicide and drug abuse. ${ }^{5-12}$ Additionally a history of sexual abuse is associated with poor physical health and the consequences may be long term. ${ }^{3,13,14}$ In addition to physical and psychological trauma other complications of sexual abuse include; unwanted children, prolapsed uteruses, vagina fistulae and cervical cancer, ${ }^{15}$ increase of suicide, AIDS, sexually transmitted infection. ${ }^{16-19}$ Additionally many victims cannot afford the care they need, or do not have physical access to appropriate care needed. ${ }^{20}$

Though sexual abuse is common in African wars, the highest prevalence and the worst intensity of sexual abuse reported in the world currently is in Eastern Cong $0^{21}$ where there are about 200,000 surviving rape victims today ${ }^{20}$ with sexual abuse having been used as a weapon of war. ${ }^{22}$

Anecdotal reports indicated that sexual abuse was used as a weapon of war (terror, intimidation, punishment) in the 2007-2008post election violence in Kenya. ${ }^{23}$ Although generally many cases of rape go unreported, it is important to specifically consider the cases reported in the conflict period between December 2007 and May 2008 and compare them with both the preceding period and the period after the conflict. The year 2006 was a conflict free year for Kenya, while 2007 was an election campaign year characterized by uncertainty and mistrust. Like the year 2006 , 2009 was a peaceful year with the majority people of Kenya returning to a fairly normal life.

Since the harmful effects of sexual abuse are long lasting and sometimes lifelong clinicians should be prepared to offer both physical and psychological help to victims of rape for as long as it is required.

Kenyatta National Hospital is the main referral hospital and has a gender violence recovery centre. It was expected that any
Correspondence: Mary W. Kuria, Department of Psychiatry, University of Nairobi, P.0. Box 74846 code 00200, NBI, Kenya.

Tel. +254.0720 .755681 .

E-mail: mkuria@uonbi.ac.ke;

wangari2@yahoo.com

Key words: sexual abuse, post election violence.

Acknowledgements: the authors would like to thank Mrs. Miriam Wanjiru for secretarial services.

Contributions: MWK, principal investigator; LO, concept and design and data interpretation; YO, DB, manuscript drafting; MM, data collection, manuscript drafting.

Conflict of interests: the authors declare no potential conflict of interests.

Received for publication: 29 September 2012.

Revision received: Not required.

Accepted for publication: 24 April 2013.

This work is licensed under a Creative Commons Attribution NonCommercial 3.0 License (CC BYNC 3.0).

(C) Copyright M.W. Kuria et al., 2013

Licensee PAGEPress, Italy

Journal of Public Health in Africa 2013; 4:e5

doi:10.4081/jphia.2013.e5

increase in the number of victims of sexual abuse should be reflected in the records of patients seen at the hospital. Moreover, the Kibera informal settlement where the unrest was severe is located just about $2 \mathrm{~km}$ from KNH. Sexually abused patients are ordinarily attended to at the gender based violence recovery centre or in the Accident \& Emergency (casualty) Department. Records of all patients seen are subsequently stored in the main hospital medical records department.

The current modern criminal justice system in many countries is more lenient to rape offenders and is largely considered as unfair to sexual assault victims. ${ }^{8}$ The criminal proceeding of rape cases appears to put the victim and her behavior on trial rather than the defendant. ${ }^{9}$ This may explain why most of the victims of sexual abuse do not report the incidences. Additionally, the perception that rape is unique to women and never occurs to men is outdated ${ }^{10}$ and other laws have eliminated the term rape altogether. ${ }^{11}$ Proper documentation of the sexual abuse in medical notes is important for criminal proceedings.

In Kenya the Ministry of Health has provided a structured format for guiding the physician on mandatory required information when evaluating victims of sexual abuse. This structured form is referred to as Post Rape Care Form 1-Ministry of Health no. 363 (PRC1- 
MOH363). This is an important document that is latter used to complement the police forms (P3) which is a legal document presented to court for prosecution of apprehended sexual abusers.

\section{Materials and Methods}

The study was conducted at Kenyatta National Hospital, which is Kenya's main referral hospital. After receiving ethical clearance by the $\mathrm{KNH} /$ University of Nairobi ethical review board, the principal investigator requested the $\mathrm{KNH}$ administration to avail records of patients treated for sexual abuse between the years 2006-2009. A researcher designed and administered questionnaire was used to extract necessary data from the patients file. The researcher completed a serialized questionnaire for each case. Required patient information on all patients treated for sexual abuse of any type including, rape and sexual defilement was obtained. Information obtained included: sex, age, residence, whether they were treated as outpatient or inpatient, management given and the month of the reported rape was obtained. All the completed questionnaires were given a serial and stored in a locked cabinet. The data was then entered in to a computer and analyses done.

Confidentiality was maintained and no name or identifying data was attached to the information obtained.

\section{Eligibility criteria}

All recorded cases of patients seen at $\mathrm{KNH}$ with diagnosis of sexual abuse of any nature in the year 2006 to 2009 were included in the study.

\section{Instrument}

A structured researcher designed questionnaire was used. Data was extracted from the completed PRC1-MOH363 form. This is a form that must be filled by the physician for every patient seen at all the ministry of health facilities for all sexual abuse victims. This form is provided by Ministry of Health and provides the national rape management guidelines for examination and documentation of all survivors of rape/sexual assault. Accurate completion of the PRC1-MOH363 is therefore very important.

\section{Results}

\section{Socio demographic characteristics}

The majority of the cases treated for sexual abuse between the years 2006-2009 were female $91.5 \%$. There was a statistically significant increase (P value 0.12) in the number of males seen in the year 2007. The majority of abused persons were under 23years of age with no statistically significant difference in the patients over the 4 years ( $\mathrm{P}$ value 0.144 ). The majority of the participants were of primary education level with was no statistically significant difference in the education level of the reported sexual abuse cases ( $P$ value 0.719). Much of the information was missing from the files especially that regarding, education, occupation, marital status and age.

Details of the socio-demographic characteristics of cases are shown in Table 1.

\section{Reported cases of sexual abuse 2006-2009}

The numbers of sexually abused persons treated at hospital increased in the years 2007 and 2009 as compared to the years 2006. A drop in the number of reported cases occurred in the year 2008. The results are shown in Table 2.

\section{Post-HIV-exposure prophylaxis}

Post-exposure prophylaxis (PEP) was given to $50.1 \%$ of the cases over the 4 years, $14.3 \%$ did not receive HIV PEP while for $34.9 \%$ the data on whether the victims received PEP was missing. The results are shown in Table 3.

\section{Patients' records}

The patient's clinical notes were poorly recorded, with information necessary for legal use missing. A total of 46 (16.9\%) files had incomplete socio demographic information missing while $83.1 \%$ had the complete information recorded. Although the PRC1-MOH363 is a useful document that doctors attending to the sexual abuse victim must complete, only 9.9\% were fully completed. Despite the PRC1MOH363 been a useful document that doctors attending to the sexual abuse victim must complete, only $9.9 \%$ were fully completed. There was however a statistically significant improvement in the completeness of patients' demographic data records over the 4 years ( $P$ value 0.00 ).

\section{Discussion}

The majority of the persons allegedly abused sexually between the years 2006-2009 and attended to at $\mathrm{KNH}$ were female. There was however a statistically significant increase in the number of males abused in the year 2007. There was also an increase in the numbers of sexually abused persons in the same year as compared to the year 2006 and 2008. Sexual abuse to women has been reported to increase in times of war where men consider women humiliation as a sign of triumph. ${ }^{6}$ The year 2007 was an election year with election campaign. The resulting post-election conflict may have provided an enabling environment for sexual offenders to perpetuate the crime; on the other hand, sexual abuse may have been

Table 1. Socio-demographic characteristics of the victims of sexual abuse.

\begin{tabular}{lcc} 
Characteristics & Number & Percentage \\
Marital status & & \\
Married & 3 & 1.1 \\
Single & 90 & 33.1 \\
Total & 93 & 34.2 \\
Missing data & 179 & 65.8 \\
Age & & \\
$<18$ & 77 & 28.3 \\
$18-23$ & 62 & 22.8 \\
$>40$ & 13 & 4.8 \\
$24-40$ & 56 & 20.6 \\
Total & 208 & 76.5 \\
Missing data & 64 & 23.5 \\
\hline Sex & & \\
Male & 22 & 8.1 \\
Female & 249 & 91.5 \\
Total & 271 & 99.6 \\
Missing & 1 & 0.4 \\
Education level & & \\
None & 1 & 0.4 \\
Primary & 28 & 10.3 \\
Secondary and above & 3 & 1.1 \\
Missing data & 240 & 88.2 \\
Total & 272 & 100.0 \\
\hline Occupation & & \\
Unemployed & 11 & 4.0 \\
Employed & 1 & 0.4 \\
Business & 5 & 1.8 \\
Student & 28 & 10.3 \\
Total & 45 & 16.5 \\
Missing data & 227 & 83.5 \\
\hline
\end{tabular}

Table 2. Number of sexually abused cases in a year.

\begin{tabular}{lcc} 
Year & Frequency & Percentage \\
2006 & 62 & 22.8 \\
2007 & 74 & 27.2 \\
\hline 2008 & 62 & 22.8 \\
2009 & 74 & 27.2 \\
\hline Total & 272 & 100.0 \\
\hline
\end{tabular}

Table 3. Post-exposure prophylaxis.

\begin{tabular}{lcc} 
Administered & Frequency & Percentage \\
No & 39 & 14.3 \\
Yes & 138 & 50.7 \\
\hline Total & 177 & 65.1 \\
Missing data & 95 & 34.9 \\
\hline Total & 272 & 100.0 \\
\hline
\end{tabular}


used as a weapon by the warring ethnic groups to harm each other.

Sexual abuse victims are at risk of contacting sexually transmitted diseases and prevention of such diseases is of paramount importance. Only slightly above half of the cases (50.7\%), had HIV post exposure prophylaxis, $14.3 \%$ did not receive HIV PEP while in $34.9 \%$ had information on whether they were given PEP or not missing. HIV been one of the dreadful consequences of rape should be prevented and doctors should give PEP and keep record of prophylactic measures taken to prevent the infection indicated and if not reasons should be recorded.

The study shows a statistically significant improvement in socio demographic data collection by the hospital staff over the 4 years with information about the education level, occupation and marital status missing in most of the cases. Possible reasons for such missing data may be due to three factors. Firstly the emergency nature of the patients' presentation may overwhelm the attending personnel, who may ignore certain information recording requirements. Secondly the attending doctor may emphasize the treatment aspects of management and ignore the importance of gathering complete patient information. Thirdly the patient may be too traumatized by the event and unable to provide the information. Irrespective of the reasons for the missing demographic data and other data, this is likely to result to poor criminal proceedings against accused offenders if brought to court for trial. Medical information on sexually abused cases is useful to the courts and inadequate information is likely to weaken the court cases against the perpetuators of the sexual crime if insufficient. Proper training of clerks and physicians on the need to collect and record detailed information from victims of sexual abuse is important.

Further training of medical professionals on importance of PEP will reduce the chances of developing HIV/AIDS, which is one of the worst consequences of sexual abuse. It is a responsibility of African leaders the need to avoid postelection conflicts in order to reduce the chances of their armies using sexual abuse as a weapon.

\section{References}

1. BBC News. Africa war zones' 'rape epidemic'; February 13, 2008. Available from: http://news.bbc.co.uk/2/hi/africa/7242421.s tm

2. Wikipedia. 2007-08 Kenyan crisis. Available from: http://en.wikipedia.org/ wiki/2007-08_Kenyan_crisis

3. Okwemba A. Kenyatta Hospital strained as poll chaos rape victims flood its recovery centre. All Africa Global Media, 31 May 2008. Available from: http://allafrica. com/stories/200806020114.html

4. IRIN. Kenya: Sexual violence still a major urban threat. Thomson Reuters Foundation, 27 October 2011. Available from: http://www.trust.org/item/20111027150000 -p57gx/?source $=$ search

5. McCauley J, Kern DE, Kolodner K, et al. Clinical characteristics of women with a history of childhood abuse: unhealed wounds. JAMA 1997;277:1362-8.

6. Paolucci EO, Genuis ML, Violato C. A metaanalysis of the published research on the effects of child sexual abuse. J Psychol 2001;135:17-36.

7. Molnar BE, Buka SL, Kessler RC. Child sexual abuse and subsequent psychopathology: results from the National co-morbidity survey. Am J Public Health 2001;91:753-60.

8. Mullen PE, Martin JL, Anderson JC, et al. Childhood sexual abuse and mental health in adult life. Br J Psychiatry 1993;163:21732.

9. Wise LA, Zierler S, Krieger N, Harlow BL. Adult onset of major depressive disorder in relation to early life violent victimization: a case-control study. Lancet 2001;358:8817.

10. Brown J, Cohen P, Johnson JG, Smailes EM. Childhood abuse and neglect: specificity of effects on adolescent and young adult depression and suicidality. J Am Acad Child Adolesc Psychiatry 1999;38:1490-6.

11. Wilsnack SC, Vogeltanz ND, Klassen AD, Harris TR. Childhood sexual abuse and women's substance abuse: national survey findings. J Stud Alcohol 1997;58:264-71.

12. Walker EA, Gelfand A, Katon WJ, et al. Adult health status of women with histories of childhood abuse and neglect. Am J Med 1999;107:332-9.
13. Hulme PA. Symptomatology and health care utilization of women primary care patients who experienced childhood sexual abuse. Child Abuse Negl 2000;24:147184.

14. Golding JM. Sexual assault history and limitations in physical functioning in two general population samples. Res Nurs Health 1996; 19:33-44.

15. McCrummen S. Prevalence of rape in E. Congo described as worst in world. The Washington Post, 9 Septeember 2009. Available from: http://www.washingtonpost.com/wp-dyn/content/article/2007/09/ 08/AR2007090801194.html

16. Mukundwa A. Documenting violence against rwandese women during the 1994 genocide. Kampala: Isis-WICCE 1998- 99 Institute; 1999.

17. UNAIDS. AIDS and the military; joint United Nations programme on HIV/AIDS. Geneva: UNAIDS Best Practice Collection; 1998.

18. Rehn E, Sirleaf Johnson E. Women, war and peace: the independent experts' assessment on the impact of armed conflict on women and the role of women in peace-building. New York: United Nations Development Fund for Women (UNIFEM); 2002. p 1. Available from: http://pendientedemigracion.ucm.es/cont/descargas/documento7201.pdf?pg=cont/descargas/document07201.pdf

19. Amnesty International. 2004, Rwanda: "Marked for Death", rape survivors living with HIV/AIDS in Rwanda; 5 April 2004. p 3. Available from: http://www.amnesty. org/en/library/info/AFR47/007/2004/en

20. Elbe S. HIV/AIDS and the changing landscape of war in Africa. Int Security 2002;27 159-77.

21. Médecines Sans Frontières (MSF). Enough is enough, sexual violence as a weapon of war; 8 March 2004. Available from: http://www.doctorswithoutborders. org/publications/article.cfm?id=1388\&cat =ideas-opinions

22. Cochrane K. The victims witness. The Guardian, 9 May 2008. Available from: http://www.guardian.co.uk/film/2008/may/0 9/women.congo

23. Kort M. A Conversation with Eve Ensler: femicide in the Congo. MS Magazine; 18 September 2007. Available from: http:// www.msmagazine.com/ 